\title{
Taalgesindhede teenoor Afrikaans - 'n verkenning vanuit taalteoretiese perspektief
}

\author{
Marlene Verhoef \\ Departement Tale \\ Vaaldriehoekkampus \\ Potchefstroomse Universiteit vir $\mathrm{CHO}$ \\ VANDERBIJLPARK
}

\begin{abstract}
Language attitudes towards Afrikaans - a reconnaisance from a theoretical point of view
\end{abstract}

The main aim of this article is to investigate the language attitude issue from a viewpoint embedded in the theory of language planning. This study was initiated by the fact that, although the public debate regarding Afrikaans is articulated in a lively way, it seems as if it does not benefit the official status of the language. The statement that this hampering effect on Afrikaans is partially caused by negative language attitudes and a lack of language loyalty by the primary and secondary speech communities serves as point of departure for this article. By looking at language attitudes departing from a theoretical language planning framework, the investigator is enabled to derive scientifically clear conclusions regarding the language attitudes of speech communities. This article also discusses the different components of language attitudes in general and the methodology regarding the investigation of language attitudes.

The second part of the article presents a brief discussion of language attitude studies undertaken in South Africa, especially those dealing with Afrikaans.

The article concludes with the statement that language planners must give considerable attention to language attitudes and their influence on language planning efforts. When this problematic issue is ignored the outcome of language planning projects will show a low success 
rate. This is of particular importance for the survival of Afrikaans in the multilingual South African society.

\section{Probleemstelling en aktualiteit}

Die openbare gesprek rondom Afrikaans het in die besonder momentum begin kry toe daar in die vroeë negentigerjare begin is met veelpartyonderhandeling oor 'n nuwe grondwet vir Suid-Afrika. Ten spyte van dié in diepte gesprekke (ook op akademiese terrein) verkeer veral die amptelike status van Afrikaans onder druk - in só 'n mate dat, nieteenstaande die grondwetlike verskansing van die taal se posisie, die taalpraktyk neerkom op die vermindering van die status van Afrikaans (Carstens, 1994:20-21).

Hierdie stelling word gemotiveer deur die volgende voorbeelde wat oor die algemeen die statusverlies wat sedert 1994 beleef word, verteenwoordig:

* Die posisie van Afrikaans as algemene administrasie- en handelstaal verswak merkbaar: groot maatskappye soos die WNNR, SABS, die NOK, die Raad op Tariewe en Handel publiseer poste-advertensies slegs in Engelstalige koerante (Beeld, 14 Februarie 1995); die SuidAfrikaanse Nasionale Weermag gebruik slegs Engels as administrasietaal (Rapport, 29 Januarie 1995).

* In hul poging om 'taalregverdigheid' teen Desember 1997 te bereik, word Afrikaans gemarginaliseer tot 'n derde televisiekanaal wat sy uitsending hoofsaaklik toespits op 'n plattelandse gehoor met 'n lae onderwyspeil (Beeld, 26 April 1995; Rapport 30 April 1995).

* Ongeag die feit dat Afrikaans een van die amptelike tale van die Vrystaatprovinsie is, is ' $n$ besluit geneem dat alle amptelike korrespondensie voortaan slegs deur medium van Engels sal geskied (Beeld, 21 April 1995).

* Die stadsraad van Sasolburg het 'n besluit geneem dat Engels vanaf Maart 1995 die enigste administrasietaal sal wees ten spyte van die feit dat Afrikaanssprekendes die grootste bydrae tot dienstegeld vir dié derdevlakregering lewer (Beeld, 28 Februarie 1995; Vaalweekblad, 10 Maart 1995).

* $\quad$ Sedert pres. Nelson Mandela se 1994-toespraak in Stellenbosch toe gesê is dat tradisioneel Afrikaanstalige universiteite aan die hele Suid-Afrika behoort en daarom toegankliker moet wees vir swart 
studente wat Engels as voertaal verkies, verloor Afrikaans toenemend status as onderrigtaal (Rapport, 5 Maart 1995). Die Universiteit van Pretoria het besluit dat Engels voortaan een van die onderrigtale moet wees (UP-Prospektus, 1994); aan die Vaaldriehoekkampus van die PU vir CHO word 'n dubbelmediumtaalbeleid gevolg en die hoofkampus van die PU verkeer onder druk om, ten spyte van 'n minderheidsvoorkeur vir Engels, op stelselmatige wyse Engels as een van die voertale in te voer (Beeld, 27 Maart 1995). Die ANC in die Gautengprovinsie het 'n ultimatum aan Afrikaanse skole gerig en geëis dat hulle hul staatsubsidie kan verbeur indien hulle nie na 'n dubbelmediumtaalbeleid oorskakel nie (Rapport, 29 Januarie 1995).

* Die nasionale Grondwetskrywende Vergadering het 'n besluit geneem om alle amptelike publikasies slegs in Engels te publiseer (Rapport, 29 Januarie 1995).

Dit word dus duidelik dat 'n probleemsituasie bestaan en dat die omstandighede vir Afrikaans versleg ten spyte van lewendige openbare gesprek. Die aanname van hierdie artikel is dat een van die aanleidende oorsake tot die verslegtende posisie van Afrikaans 'n negatiewe taalhouding is waar 'n gebrek aan taallojaliteit van die breë spraakgemeenskap medeverantwoordelik is vir die verlies aan taalstatus. Dit word verder gerelativeer deur die feit dat die status, waarde en belangrikheid van 'n taal op 'n bepalende wyse gemeet word aan mense se gesindheid teenoor daardie taal; daarom het houdings/gesindhede wat teenoor 'n taal/variëteit ingeneem word ' $n$ baie groot invloed - of op die taal/variëteit se behoud of herlewing, of op sy agteruitgang en uiteindelike ondergang (Baker, 1992:9).

Die volgende vertrekpunte lê dié artikel ten grondslag: 'n ondersoek na die breë Suid-Afrikaanse gemeenskap se taalgesindhede teenoor Afrikaans behoort 'n aanduiding te gee van die primêre en sekondêre taalgemeenskappe se veranderende oortuigings, voorkeure en verwagtinge insake Afrikaans - oortuigings en voorkeure wat weer op hul beurt die oënskynlike taalverskuiwingsproses weg van Afrikaans behoort te verklaar.

Aangesien taalgesindhede ' $n$ bepaalde doel dien as sosiale merker van veranderende gemeenskapsopvattings oor 'n taal, het die studie van taal- 
gesindhede waarde vir taalbeplanning. Die implikasie daarvan is dat, indien taalhoudings op pertinente wyse verdiskonteer word binne die doelwitstellingsfase van enige taalbeplanningsprogram, daar verseker word dat die uiteindelike afloop van taalbeplanning verantwoordbaar is (Van der Merwe, 1990:188; Verhoef, 1991:319).

Die doel met hierdie artikel is om die kwessie van taalgesindheid vanuit 'n taalteoretiese raamwerk te ondersoek en dan oorsigtelik verslag te gee van die stand van taalgesindheidstudie ten opsigte van Afrikaans vanuit die primêre en sekondêre taalgemeenskappe.

\section{Taalgesindheid/-houding: 'n begripsverheldering en omskrywing}

Binne die Afrikaanse taalkundige vakliteratuur (Swanepoel, 1992; Webb, 1992; Steyn, 1980 en 1992; De Villiers, 1992) word die begrip houding deurgaans as sinoniem vir die Engelse woord attitude gebruik. (Tóg toon Prinsloo, (1984:106 e.v.) en Du Plessis, (1992:12, 16, e.v.) voorkeur vir die begrip gesindheid.) Aangesien begripsverwarring kan bestaan tussen die begrippe gesindheid en houding, word 'n kort begripsverklaring van albei begrippe voorgehou en word daarna gemotiveer waarom gesindheid vir die doeleindes van hierdie artikel as die bruikbaarste begrip beskou word.

Die WAT (Band 4, 1972) omskryf houding as (fig.) "[m]anier van doen, handel, optree, gedrag".

Daarteenoor word gesindheid (WAT, Band 3, 1972) omskryf as "'n [d]enkwyse, stemming, innerlike gevoel of houding; som van menings, oortuigings wat as waar aanvaar word en wat as rigsnoer dien by geestelike handelinge of aanleiding daartoe gee; innerlike wilsgesteldheid".

Dit blyk uit bogenoemde begripsverklaring dat die woord gesindheid méér weergee van die innerlike ingesteldheid wat as dryfveer vir uiterlike optrede dien as wat die woord houding doen. Ook skyn dit of houding bestempel kan word as die uiterlike manifestasie van 'n innerlike gesindheid.

Gesien in die lig van 'n algemene omskrywing van gesindheid kan taalgesindheid dan omskryf word as 'n individuele of kollektiewe som van 
menings/stel oortuigings (wat kan wissel van positief tot negatief) teenoor ' $n$ bepaalde taal/variëteit en sy sprekers. Hierdie ingesteldheid is bepalend vir spraakgemeenskappe en individuele lede van spraakgemeenskappe se persepsies en optrede teenoor sodanige tale/variëteite en hul sprekers.

Volgens Fishman (1976:331) omvat die begrip taalgesindheid die volledige gevoelspektrum teenoor ' $n$ taal of variëteite. Hierdie spektrum kan strek van taallojaliteit aan die een kant wat uitdrukking vind in 'n gevoel van taalnasionalisme tot taalantipatie aan die ander kant wat uitdrukking vind in ' $n$ bewustelike verwerping van ' $n$ taal/variëteit en sy sprekers.

\section{Die komponente van (taal)gesindhede}

Baker (1992:12 e.v.; kyk ook Gouws et al. (1979)) maak 'n driedeling om die verskillende komponente van houdings/gesindhede (en daarom ook van taalgesindhede) te omskryf: daar word naamlik onderskei tussen die kognitiewe, affektiewe en konatiewe eienskappe van gesindhede.

* Die kognitiewe gesindheidskomponent kom na vore in gedagtes oor en oortuigings wat ' $n$ individu/spraakgemeenskap teenoor ' $n$ taal/ variëteit huldig. Daar word vanuit die kognitiewe sfeer beredeneer wanneer, ter illustrasie, die mening gehuldig word dat 'n sekere taal voortbestaansmoontlikhede het en dat dit ' $n$ bepaalde rol te speel het in 'n spesifieke kultuuroordragingsproses. Hierdie innerlike mening bring dan mee dat individue/spraakgemeenskappe positief ingestel sal wees teenoor sodanige taal/variëteit.

Die kognitiewe aspek van gesindhede bring mee dat aanvaar kan word dat gesindhede nie aangebore menslike eienskappe is nie, maar dat dit op grond van leerprosesse en ervarings ontwikkel word (Swanepoel, 1992:134).

* Die affektiewe komponent kom na vore in gevoelens (wat onder andere op vorige kenniservaring en sentimente gebaseer is) wat op individuele of kollektiewe wyse teenoor 'n sekere taal/variëteit gekoester word. Dit kom tot uiting in 'n voorliefde/affmiteit vir of afkeer van ' $n$ taal of sy sprekers. Aangesien alle kognitiewe oortuigings nie ewe swaar gewig dra in die affektiewe beoordeling van 'n objek (in dié geval 'n taal/variëteit) nie, het mense, ten spyte van 
dieselfde kennisstruktuur, verskillende waarde-oordele ten opsigte van 'n sekere objek (Swanepoel, 1992:134).

Baker (1992:12) wys daarop dat daar dikwels 'n diskrepans kan bestaan tussen die kognitiewe en affektiewe komponente van gesindheid. Ter illustrasie: hoewel daar oor die algemeen 'n positiewe gesindheid teenoor 'n sekere taal kan bestaan, kan 'n negatiewe gevoel ervaar word oor byvoorbeeld die voortbestaan van sodanige taal as ampstaal of as onderrigmedium.

* Die wils- of konatiewe komponent van gesindhede behels 'n "gereedheid vir optrede" (Baker, 1992:13) of gedragsintensie (Swanepoel, 1992:134). Hierdie gedragsaspek kom na vore onder bepaalde omstandighede. Wanneer individue/taalgemeenskappe positief teenoor 'n sekere taal/variëteit ingestel is, kom die wilsaspek byvoorbeeld daarin na vore dat mense besluit dat daardie taal die onderrigmedium moet wees waardeur hul kinders geletterd kom, of op die manier waarop hulle aandring op daardie taal se taalregte. (Indien die gesindheid negatief is, sal dit uiteraard na vore kom in 'n taalverskuiwingsproses ten koste van sodanige taal.)

Ten spyte van die feit dat gesindhede in drie duidelik onderskeibare komponente verdeel is - 'n verdeling wat ' $n$ wetenskaplike aanpak van die studie van taalgesindhede behoort te vergemaklik, word dit bemoeilik deur die teenstrydigheid wat mag bestaan in dit wat individue/taalgemeenskappe as hul gesindheid voorhou en dit wat werklik die gesindheid teenoor die taal is en wat die optrede teenoor sodanige taal/variëteit en sy sprekers motiveer (Swanepoel, 1992:134).

\section{Taalgesindhede as merker van sosiale verandering}

Webb (1992:434) dui aan dat taalgesindhede 'n belangrike gemeenskapsrol vervul omdat dit 'n wesentlike invloed uitoefen op die ekonomiese, opvoedkundige en sosio-maatskaplike funksionering van 'n taalgemeenskap. Indien 'n taal beperkte hoëfunksiestatus geniet, geskied die opvoeding deur medium van 'n tweede of vreemde taal en word die taalgemeenskap weerhou van potensieel goeie beroepsmoontlikhede. Hierdie situasie het uiteraard ' $n$ bepalende rol te speel in die taalkeuses wat taalgemeenskappe maak en in hul persepsies van sodanige taal se status. 
Botsende taalgesindhede kan ook die teelaarde voorberei vir moontlike politieke konflik omdat negatiewe en positiewe gesindhede teenoor mekaar te staan kan kom en verreikende invloed op die status, voortbestaan en beplanning vir sodanige taal kan hê. Webb (1992:434) beredeneer die feit dat die uitdrukking van botsende taalgesindhede aanleiding kan gee tot taalkonflik: indien 'n persoon/taalgemeenskap of aandring op bediening in die taal van sy keuse, of weier om 'n bepaalde taal anders as die een van sy keuse te gebruik, kan dit of 'n aanduiding wees van 'n oordrewe taallojaliteit, of van 'n gevoel van bedreigdheid.

Aan die ander kant weer, kan positiewe taalgesindhede ' $n$ bepalende rol speel in ' $n$ nasiebouproses en kan dit as ' $n$ kragtige instrument gebruik word om taalgemeenskappe na dieselfde doelwitte te laat streef.

\section{Die studie van taalgesindhede - 'n taalteoretiese terreinafbakening}

Navorsing oor taalgesindhede word onderneem sodat die sosiale betekenis van sekere tale/variëteite bepaal kan word en om agter te kom watter rol onderliggende gesindhede speel in sprekers se taalgebruik en taalkeuse (Agheyisi \& Fishman, 1970:144).

Gesindhede is sosio-maatskaplike, emotiewe, menslike eienskappe (vgl. Paragraaf 3 ) en hoort as sodanig binne die sosiale psigologie tuis. Daarteenoor bring die toegepaste linguistiese aard van taalgesindhede mee dat 'n studie van taalgesindhede nie bloot vanuit die psigologiese hoek benader kan word nie. Om hierdie rede moet enige studie oor taalgesindhede op 'n interdissiplinêre wyse aangepak word waar in 'n groot mate geleun moet word op die vertrekpunte van sowel die sosiolinguistiek as die sosiale psigologie.

Wanneer dit gaan om die bestuur of beplanning van taalgesindhede as een van die produkte van taalbeplanning, word dit duidelik dat taalgesindhede primêr tuishoort binne 'n studie van taalbeplanning en binne hierdie taalteoretiese raamwerk verdiskonteer moet word.

Taalbeplanning word gedefinieer as die toekomsgerigte, georganiseerde bestuur van taalprobleme met die oog op doelbewuste taalverandering aan die hand van 'n stel doelwitte (Du Plessis, 1989:272; Van der Merwe, 
1990:185; Verhoef, 1991:282). In dié proses moet rekening gehou word met die sosio-kulturele omgewing waarin die taalprobleem voorkom. Die literatuur oor die wetenskap van taalbeplanning onderskei drie tipes taalbeplanning: korpus-, status- en taalverwerwingsbeplanning (Cooper, 1989:31-33). Hoewel daar 'n sterk oorvleueling en interafhanklikheid in dié drie tipes taalbeplanning is en elkeen implikasies het vir die ander twee, hoort 'n studie van taalgesindhede tuis binne taalstatusbeplanning.

Die motivering vir hierdie kategorisering van taalgesindhede in taalstatusbeplanning lê daarin dat taalstatusbeplanning primêr gaan oor die klaarheid wat verkry moet word ten opsigte van botsende taalnorme (Haugen, 1983:270), oor die bestuur van taalgedrag (Cooper, 1984:17) en oor die bepaling van taalvoorkeure (Van der Merwe, 1990:188). Hierdie drie aspekte van statusbeplanning het al drie ten nouste te make met die bestuur van taalgesindhede. Die implikasie van hierdie kategorisering is dan dat elke taalbeplanningsprojek wat daarop gemik word om die status van 'n sekere taal/variëteit te bestuur, op 'n pertinente wyse rekening moet hou met die taalgesindhede van die kliënte van sodanige taalbeplanningsprojek. Vir die doeleindes van taalstatusbeplanning kan negatiewe taalgesindhede wat uitdrukking vind in taalantipatie geïdentifiseer word as taalprobleme wat bestuur moet word.

Ter wille van die bevredigende oplossing van die taalprobleem wat die spesifieke taalbeplanningsprojek geïnisieer het, moet strategieë ter opbou van die primêre en sekondêre taalgemeenskappe se taalgesindhede reeds in die doelwitbepalingsfase vir taalstatusbeplanning geïdentifiseer word en moet dit deurlopend in die implementerings- en evalueringsfases bestuur word (Verhoef, 1991:319).

'n Bykomstige faktor ten opsigte van taalgesindhede binne die raamwerk van statusbeplanning is die reaksie van die kliënte op 'n gekose taalnorm. Rubin (1983:334) dui aan dat die teikengroep op wie 'n sekere taalstatusbeplanningsproses gemik is van kardinale belang is as die dekodeerders van sodanige proses omdat hulle die nuwe taalvorme, wat die resultaat is van 'n sekere taalkorpusbeplanningsproses, hul eie moet maak of verwerp. Juis dit het 'n bepaalde invloed op hul persepsies van so 'n taal of variëteit. 
Dit kan nooit uit die oog verloor word nie dat die sosiale karakter van taal meebring dat omringende sosio-politieke gebeure 'n kardinale invloed uitoefen op die kliënte van taalbeplanning se aanvaarding of verwerping van ' $n$ beplande taalbeplanningsproses en dat juis dié omliggende gebeure in aanmerking geneem moet word wanneer dit oor 'n studie van taalgesindhede gaan.

Die implikasie van die voorafgaande paragrawe is dat, alvorens werklike toekomsgerigte taalbeplanning vir Afrikaans gedoen kan word, negatiewe taalgesindhede as taalprobleem geïdentifiseer word - ' $n$ taalprobleem wat remmend op taalbeplanningsprojekte vir die taal inwerk. Taallojaliteit en taalantipatie kan nooit los gesien word van sekere ideologiese raamwerke nie (Wardhaugh, 1987:1). Om hierdie rede moet die staatkundige verandering in ons land, waar Afrikaanssprekendes nie meer in oorwegend beleidmakende posisies staan nie en waar Afrikaans se simboolwaarde steeds as negatief geklassifiseer word (Du Plessis, 1992:49), bo alle twyfel 'n invloed hê op die primêre én die sekondêre spraakgemeenskappe se persepsies teenoor Afrikaans en die sprekers van Afrikaans.

Die noodsaak vir ' $n$ teoretiese onderbou by die studie van taalgesindhede lê vervolgens daarin dat taalveranderingsprosesse (en alle dinamies lewende tale word aan verandering onderwerp) nie net in die formele strukture van 'n taal plaasvind nie, maar ook in die persepsies wat sprekers teenoor 'n taal huldig. Hierdie feit het bepaald verreikende gevolge op enige taalgemeenskap se eie taalgesindheid en -lojaliteit en moet verdiskonteer word wanneer taalbeplanning vir sodanige taal gedoen word.

\section{Verskillende faktore wat as determinante vir die bepaling van taalgesindhede optree}

Verskillende hooffaktore wat taalgesindhede determineer, word geïdentifiseer, naamlik taalgedrag, sosiale oordele, beleidsvoorkeure en institusionele ondersteuning (Webb, 1992:436 e.v.). Elkeen van hierdie faktore kan in verskillende onderafdelings verdeel word:

* Taalgedrag as konatiewe uitdrukkingsmiddel van die onderliggende taalgesindheid word gedetermineer deur taalkennis, taalvoorkeur, kodewisseling en taalverskuiwingspatrone. 
* $\quad$ Sosiale oordele is menings wat deur individue of taalgemeenskappe gehuldig word aangaande die sosiale omgewing wat 'n taal/variëteit en sy sprekers omgeef, en het 'n wesentlike invloed op die individuele en kollektiewe taalgesindheid wat teenoor sodanige taal/ variëteit gehuldig word. Faktore soos stereotipes, waardeoordele oor tale/variëteite en sosio-kulturele identiteit kan sosiale bepalers wees van sprekers se taalgesindhede. Sodanige taalgesindhede wat deur sosiale oordele gedetermineer word, word hoofsaaklik gemotiveer vanuit die affektiewe (tesame met die kognitiewe komponent).

* Taalbeleidskwessies word op nasionale vlak beheer en oefen 'n wesentlike invloed op taalgemeenskappe se taalvoorkeure en daarom uiteindelik ook op hul taalgesindhede uit. Die faktore wat in hierdie verband ' $n$ rol speel, is die nasionale taalbeleid, die opvoedkundige voertaalbeleid en leerlinge se gesindhede teenoor taalvakke op skool.

Hierdie drie faktore is reële gegewe op makrovlak waarop individue of taalgemeenskappe deur hul gehuldigde taalgesindhede reageer. Beleidsfaktore funksioneer dus vanuit die kognitiewe komponent van gesindhede en werk as ekstrinsieke manipuleerder van taalgesindhede.

* Institusionele ondersteuning is 'n aanduiding van hoe hoog of hoe laag tale/variëteite deur verskillende gemeenskapsinstellings aangeslaan word, en het ' $n$ bepalende invloed op individue of taalgemeenskappe se gesindheid teenoor daardie tale of variëteite. Regeringsinstellings, kultuurinstellings en die massamedia is tipiese manipuleerders wat taalgemeenskappe se gesindhede teenoor daardie tale/variëteite en die sprekers van sodanige tale/variëteite vorm.

Hierdie determinant werk ook vanaf die makrovlak en tree as manipuleerder van individue en gemeenskappe se taalgesindhede op. Die simpatie of antipatie wat vanaf institusionele vlak teenoor sekere tale betoon word, word in 'n groot mate bepaal deur 'n interaktiewe samespel van al drie gesindheidskomponente, naamlik die kognitiewe, die affektiewe en die konatiewe komponente. 


\section{Die metodologie van taalgesindheidstudie}

Daar bestaan meningsverskil oor die navorsingsmetodologie vir taalgesindheidstudie omdat nóg kwalitatiewe, nóg kwantitatiewe, nóg eksperimentele ondersoeke waarin taalgesindhede nagevors is, werklik afdoende bevredigende navorsingsresultate gelewer het (Saville-Troike, 1990:182). Die voor die hand liggende rede vir die onbetroubare navorsingsresultate is dat 'n poging aangewend word om ' $n$ uiters komplekse aangeleentheid soos taalgesindhede, wat 'n innerlike wilsgesteldheid is, as't ware op 'n eksterne wyse te probeer meet. Daarby kom die eis na navorsers dat gevolgtrekkings waartoe hulle kom met betrekking tot 'n spraakgemeenskap se taalgesindhede, móét korreleer met daardie spraakgemeenskap se persepsies van hul eie taal (Macauley, 1975:160; Swanepoel, 1992:134).

Dit word uit tersaaklike vakliteratuur duidelik dat 'n kwalitatiewe en kwantitatiewe tipe ondersoek die betroubaarste is wanneer 'n taalgemeenskap se gesindhede teenoor hul taal bepaal moet word (SavilleTroike, 1990:184; Agheyisi \& Fishman, 1970:141).

Oor die algemeen word drie tipes taalgesindheidstudies uitgevoer (SavilleTroike, 1990, Agheyisi \& Fishman, 1970) en, ondanks die kategorisering en verskil in klemplasing, vertoon dié tipes studie 'n groot mate van onderlinge insluiting:

* Studies wat te make het met taalgeoriënteerde of taalgerigte gesindhede oor die algemeen. Waardeoordele oor taalgebruik soos 'mooiklinkend/ontoereikend/rykgeskakeerd/ beter as 'n ander een' word in hierdie tipe taalgesindheidstudie bepaal.

* Studies wat handel oor gemeenskapsgerigte stereotiepe indrukke teenoor sekere tale/variëteite of teenoor dié tale se status of sprekers. Die navorsing wat hieruit na vore kom, is hoofsaaklik begaan oor die sosiale betekenis van tale/variëteite en handel in die besonder oor die gesindhede wat teenoor sprekers van sekere tale ingeneem word.

* $\quad$ Studies wat te make het met die analise van die invloed wat sprekers se taalgesindhede uitoefen op hul taalgedrag. Die onderwerpe wat hoofsaaklik hier onder die loep kom, is die rol wat gesindhede speel in taalkeuse en taalgebruik en taalverwerwing. 
Die volgende tipes dataversamelingstegnieke word deur Agheyisi en Fishman (1970:144 e.v.) onderskei wanneer taalgesindhede nagevors word:

* Vraelyste word gebruik wanneer taalverbintenisse op konatiewe vlak gemeet word. Hierdie tegniek werk hoofsaaklik aan die hand van die Guttmanskaal waarmee oordeelvrae gevra word om respondente se taalmenings en waardeoordele oor 'n taal/variëteit te toets.

* Vermommingstegnieke (in Engels bekend as die matched guised technique) word in die besonder gebruik om aan die hand van bandopnames onbewuste, affektiewe en stereotiepe gesindhede van sprekers te ontleed.

* Persoonlike onderhoude kan gebruik word waarmee uitsprake oor respondente se persepsies teenoor 'n taal/variëteit of sy sprekers gemonitor word. Die persoonlike onderhoud as dataversamelingstegniek is in die besonder waardevol omdat ruimte bestaan vir opvolggesprekke.

* Binne die sosiale psigologie word gebruik gemaak van gevallestudies as metode van data-insameling en data-interpretasie en daarom bied dit ' $n$ bruikbare metode om taalgesindhede te toets.

Die gekose dataversamelingstegniek vir ' $n$ spesifieke taalgesindheidstudie hang in 'n groot mate af van watter tipe studie (soos uiteengesit deur Agheyisi \& Fishman, 1970) uitgevoer word. Om werklik 'n betroubare interpretasie van taalgemeenskappe/individue se taalgesindhede te maak, word aanbeveel dat 'n verskeidenheid van dié tegnieke gebruik word.

\section{8. 'n Oorsig oor die studie van taalgesindhede in Suid- Afrika}

Die doel met die hieropvolgende bespreking is om op oorsigtelike wyse ' $n$ inventaris te bied van taalgesindheidstudies wat die afgelope 20 jaar in Suid-Afrika onderneem is. Ten slotte word 'n kritiese beoordeling gegee na aanleiding van die bevindinge waartoe telkens in die verskillende studies gekom is. 


\subsection{Vorster en Proctor (1975)}

'n Ondersoek is in 1974 geloods na eerstejaarstudente aan die Universiteit van Fort Hare in die Oos-Kaap se taalgesindhede teenoor Afrikaans en Engels. Die studie het bevind dat die respondente Afrikaanssprekendes oor die algemeen as streng, outoritêr en onsimpatiek beleef, terwyl Engelssprekendes as vriendelik en simpatiek gesien word. Hierdie stereotipering gee uiteraard ook die respondente se gesindheid teenoor die taal weer en speel 'n rol wanneer taalkeuses gemaak moet word.

Dit word uit die studie duidelik dat hierdie sekondêre taalgemeenskappe (ten opsigte van sowel Engels as Afrikaans) se gesindhede teenoor Engels meer positief is as teenoor Afrikaans.

\subsection{Navorsing van die Raad vir Geesteswetenskaplike Navorsing se Sosiolinguistiese afdeling}

In opdrag van die destydse Minister van Nasionale Opvoeding, mnr. Jan de Klerk, het die RGN se afdeling vir Sosiolinguistiek in 1970 'n ondersoek van stapel gestuur na die algemene stand van Afrikaans en Engels (as amptelike tale van die RSA) onder die breë Suid-Afrikaanse en Namibiese/ Suidwes-Afrikaanse bevolking. Teen 1975 was die veldwerk ten opsigte van die Suid-Afrikaanse bevolking afgehandel en teen Julie 1976 kon begin word om die empiriese data ten opsigte van die stand van Afrikaans en Engels in Namibië te interpreteer (Schuring, 1979:1).

Die breë opdrag met dié landwye ondersoek was om 'n sosiolinguistiese opname van blankes en swart mense se taalgebruik van Afrikaans en Engels en hul taalgesindhede teenoor die twee amptelike tale te monitor. $\mathrm{Na}$ afloop van die navorsing is 'n twintigtal publikasies ten opsigte van taalgesindhede gepubliseer (Hauptfleisch, 1983:67, 68).

Wat die stand van die primêre en sekondêre taalgemeenskappe se taalgesindhede teenoor Afrikaans en Engels betref, het Hauptfleisch (1983:36) bevind dat blanke Afrikaanssprekendes baie meer aan Engels blootgestel is as wat Engelssprekendes aan Afrikaans blootgestel is en daarom nie ' $n$ weerstand toon teen die aanleer van Engels as tweedetaal nie. Daarby het die aanleer van Engels oor die algemeen funksionele waarde vir Afrikaanssprekendes, in teenstelling met die minimale funksionele waarde van Afrikaans vir Engelssprekendes. Interessant is die 
bevinding dat Afrikaanssprekendes baie sterk met Afrikaans identifiseer en nie in noue sosiale verhoudinge (bv. in onderlinge familiebande) Engels sal praat nie (Hauptfleisch, 1983:36).

Wat die tendens van taalverskuiwing en die verskuiwing van taallojaliteite betref, het Hauptfleisch (1983:60 e.v.) bevind dat taallojaliteite verskillende betekenisnuanses vir Afrikaanssprekendes en Engelssprekendes inhou. Hy dui aan dat Afrikaans op 'n baie intiemer wyse betrokke is by die waardestelsels en tradisies van Afrikaanssprekendes as wat Engels by Engelssprekendes is. Die feit dat Afrikaanssprekendes se taallojaliteit teenoor Afrikaans 'n redelike emosionele kwessie is, het 'n bepaalde invloed op die kwessie van taalbehoud.

Hy kom tot die gevolgtrekking dat dit nie as dislojaliteit teenoor Afrikaans vertolk moet word dat A frikaanssprekendes geen weerstand teenoor Engels as tweedetaal koester en dit vryelik as kommunikasiemiddel gebruik nie (Hauptfleisch, 1983:61).

'n Verskuiwing in taallojaliteit vind plaas wanneer die eerstetaal sodanig deur die tweedetaal verplaas is dat laasgenoemde as eerstetaal optree. Hierdeur word aangetoon dat 'n volledige taalverskuiwings- en taalgesindheidsveranderingsproses voltrek is. Van die respondente wat gereageer het op die RGN-ondersoek van die sewentigerjare het slegs 3,25\% 'n totale taalverskuiwing - met die sosio-kulturele implikasies daarvan - deurloop (Hauptfleisch, 1983:61).

Schuring (1979:60 e.v.) het tot die volgende bevindings gekom oor swart gemeenskappe se taalvoorkeure ten opsigte van Afrikaans en Engels:

* Wat die grafiese vaardighede (skryf en lees) betref, word voorkeur aan Engels gegee, terwyl voorkeur aan Afrikaans gegee word ten opsigte van akoestiese vaardighede (verstaan en praat).

* 'n Groter funksionele waarde word aan Engels gegee as aan Afrikaans, hoewel Afrikaans se praktiese waarde nie geïgnoreer word nie.

* Engels het 'n baie meer gevestigde posisie in stedelike gemeenskappe waar die opvoedkundige kwalifikasies oor die algemeen redelik hoog is, terwyl Afrikaans 'n gevestigde posisie het in 
plattelandse gebiede en in gebiede waar die gemeenskap se opvoedkundige kwalifikasie oor die algemeen laag is.

Schuring (1979:61) gee 'n samevatting van die stand van Afrikaans en Engels in swart gemeenskappe en stel dat Suid-Afrikaanse swart gemeenskappe in die ouderdomsgroep 15 tot 54 'n groter prestigewaarde aan Engels as aan Afrikaans toeken, maar dat Afrikaans 'n groter pragmatiese waarde as Engels vertoon.

Wat die gesindhede van bruin mense in 1979 teenoor Afrikaans en Engels betref, het Scheffer (1983) bevind dat hierdie oorwegend Afrikaanssprekende gemeenskap 'n geneigdheid toon om Engels in winkels en sogenaamd 'hoëstatusgesprekke' te gebruik: $33,1 \%$ verkies dit om handelstraksasies in Engels te beklink en 18,4\% wanneer gesprek met mediese dokters en hooggeplaastes gevoer word. Dit blyk ook uit dié navorsing dat Afrikaans as omgangstaal die vertrekpunt is, en dat Engels as statustaal, die eindpunt is (Scheffer, 1983:103).

Cahill en Kamper (1989) het ' $n$ studie geloods na die stand, plek en rol van Afrikaans as tweedetaal in die breë kurrikulum van hoërskole van die Departement van Onderwys en Opleiding. Hulle het bevind dat daar 'n oorwegende voorkeur is vir die gebruik van Engels as kommunikasiemedium: wanneer leerlinge met onderwysers kommunikeer, verkies $61 \%$ van die respondente Engels (in teenstelling met die 6,6\% wat Afrikaans verkies) en wanneer onderwysers onderling kommunikeer, verkies $68 \%$ Engels as kommunikasiemedium (in teenstelling met $11,4 \%$ wat Afrikaans verkies).

\subsection{Afrikaanse Taal en Kultuurbond en die Universiteit van Pretoria (1985)}

Volgens Webb et al. (1992:44) het die ATKB in samewerking met die Universiteit van Pretoria in 1985 'n ondersoek geloods onder blanke Afrikaanssprekende st.9-leerlinge in Pretoria. Een van die gevolgtrekkings waartoe dié navorsing kom, is dat daar 'n toenemende verdraagsaamheid teenoor Engels en die kultuur wat daardeur verteenwoordig word, onder Afrikaanssprekendes bespeur word. 


\subsection{Kotze (1987)}

Die doel met dié navorsing aan die Afrikaanse departement van die Universiteit van Zululand was om 'n empiriese basis te verleen aan bepaalde gevolgtrekkings oor die rol wat die ervaring van Afrikaans in die houdingsvorming teenoor die taal en sy sprekers by die swart universiteitstudent as taalaanleerder speel. Ook is die invloed van moedertaalsprekers op hierdie taalaanleerders en hul houdings teenoor die taal waaraan hul blootgestel is, gemeet.

Kotze (1987:57) kom tot die gevolgtrekking dat gebrek aan kontak met moedertaalsprekers aanleiding gee tot negatiewe persepsies teenoor sowel die taal as die sprekers van daardie taal.

\subsection{Van Jaarsveld (1989)}

Hierdie navorsingsverslag van die Universiteit van die Oranje-Vrystaat is 'n weergawe van respondente uit die multikulturele Suid-Afrikaanse samelewing se siening oor onder andere die twee amptelike tale.

'n Insiggewende afleiding uit dié studie is dat op die vraag in watter een van die twee amptelike tale hoflikheid die beste uitgedruk kan word, die reaksie sodanig is dat 15 van die 76 respondente aandui dat dit in Afrikaans gedoen kan word; 34 uit die 76 gee aan Engels voorkeur en 27 van die 76 sê dat albei tale gebruik kan word om hoflikheid uit te druk.

Hoewel dié studie nie primêr onderneem is om taalgesindhede te toets nie, gee die taalvoorkeurprofiel ' $n$ duidelike aanduiding van onderliggende gesindhede.

\subsection{Louw-Potgieter en Louw (1991)}

Die taalvoorkeure vir taalbeleidstelling van studente aan die Universiteit van Wes-Kaapland is deur middel van 'n simulasie-oefening bepaal. Die bevinding was dat Afrikaans- en Engelstalige moedertaalsprekers 'n diverse taalbeleid verkies waar Afrikaans, Engels en Xhosa amptelike status geniet, terwyl Xhosasprekende moedertaalsprekers 'n tweetalige taalbeleid verkies met Engels en Xhosa as amptelike tale. Al drie taalgroepe het 'n voorkeur vir aanvanklike moedertaalonderrig op primêre skoolvlak getoon, terwyl op tersiêre vlak 'n voorkeur getoon is vir die demokraties-verkose amptelike taal/tale. In teenstelling met die Afrikaans- 
en Engelssprekende respondente wat aangedui het dat hulle die vraelys in hul moedertaal wou voltooi, het die Xhosasprekende respondente verkies om dit in Engels te doen omdat dit ' $n$ internasionale taal is.

\subsection{Booyse (1992)}

Die probleemvraag wat hierdie navorsing geïnisieer het, is die houding van leerlinge teenoor Afrikaans as skoolvak en dit wat aanleiding tot dié houding gee. Dit blyk uit die navorsing dat leerlinge nie as sodanig negatief teenoor Afrikaans as skoolvak is nie, maar dat die onderrigwyse van die vak as negatief beleef word. Hierdie negatiewe belewing gee aanleiding tot swak gemotiveerdheid ten opsigte van die vak, onderprestasie, lomp taalhantering en 'n swak uitdrukkingsvermoë.

\subsection{Jordaan, Van Rensburg en Webb (1992)}

Dié ongepubliseerde navorsingsverslag het die gesindhede van blanke st.9leerlinge aan drie hoërskole in Pretoria wat verteenwoordigend van verskillende sosio-ekonomiese lae is, gemonitor (Webb et al., 1992:37).

Afleidings oor gehuldigde taalgesindhede is onder andere gemaak op grond van die graad van kodevermenging. Die grootskaalse invloed van Engels op die woordeskat van leerlinge wie se moedertaal Afrikaans is, word hierdeur bevestig.

\subsection{Dube (1992)}

Die doel met dié navorsing was om die breë Sowetogemeenskap se mening te toets oor die tale wat hulle beïnvloed en hul taalgesindheid teenoor dié tale. Die bevinding met die navorsing is dat die gemeenskap oor die algemeen positief ingestel is teenoor Engels op grond van die funksionele aard daarvan, omdat dit as nasionale taal kan dien en omdat dit as gemeenskapstaal waarde kan hê (Dube, 1992:122). Die gesindheid teenoor Afrikaans word negatief gestem op grond van die 'onderdrukkende aard' (Dube, 1992:122) daarvan. Desnieteenstaande word dit nie geringgeskat as taal wat nié gebruik behoort te word nie, omdat dit 'n constituency het. Die oorheersende gevoel is dat dit soos enige ander taal hanteer en beskou moet word. 
Die taalgesindheid teenoor die inheemse tale is besonder positief. Tog bestaan die gevoel dat hierdie tale tot nog toe van owerheidsweë geïgnoreer is en dat hulle nou die geleentheid gebied moet word om net soos Afrikaans en Engels te ontwikkel en erkenning te kry.

Insiggewend uit dié studie is die positiewe gesindheid teenoor die bestaan van sogenaamde straattale wat as gevolg van die multitalige karakter van Soweto op funksionele grondslag ontwikkel het. Hierdie tale (meer as een variëteit word onderskei) word hoog aangeslaan deur die gemeenskap omdat dit as 'n bepaalde identifikasie- en kommunikasiemiddel gebruik word.

Dube se studie bevind ook dat die kwessie van multitaligheid op positiewe wyse ervaar word deur die Sowetogemeenskap. Multitaligheid bewys dat die een taal nie verhewe bo ' $n$ ander een is nie en dat mense die vryheid geniet om die taal van hul keuse te gebruik (Dube, 1992:123).

Daarbenewens is ook bevind dat die gemeenskap gekant is teen die idee van sogenaamde gestandaardiseerde Sotho en Nguni omdat dit belangrike ontwikkelingsgeleenthede aan die onderskeie inheemse tale sal ontneem.

\subsection{Coetser (1993)}

In dié navorsing is die gesindhede teenoor Afrikaans as sodanig en teenoor Afrikaans as kommunikasiemedium bepaal aan die hand van 800 vraelyste aan persone wat in Transkei woonagtig is. Die respondente is persone wat of Afrikaans as moedertaal het óf Afrikaanstweetalig is.

Die gevolgtrekking waartoe Coetser (1993:126) kom, is dat die respondente wie se moedertaal Afrikaans is, positief teenoor die taal is. Vervolgens dui die navorsing daarop dat die moontlikhede van Afrikaans as kommunikasietaal in die Transkei beperk is omdat daar op openbare terrein in 'n beperkte mate van Afrikaans gebruik gemaak word.

\subsection{De Klerk en Bosch (1994)}

Hierdie navorsing is onderneem om gesindhede van Oos-Kapenaars teenoor die drie hooftale van die streek, Afrikaans, Engels en Xhosa, te meet. 
Die belangrikste bevinding van hierdie studie is die oorwegend taalkundige onsekerheid van Afrikaans- en Xhosasprekendes oor hul eie tale (De Klerk \& Bosch, 1994:57). Hoewel hul op emotiewe vlak oorwegend positief teenoor hul eie tale voel, is daar op rasionele vlak 'n aangetrokkenheid teenoor Engels en die kultuur wat daardeur verteenwoordig word. Op onbewustelike vlak neem Afrikaanssprekende respondente 'n positiewe gesindheid in teenoor Afrikaans, hoewel die ontleding van die vraelys daarop wys dat daar nie werklik vertroue is in Afrikaans nie. De Klerk en Bosch (1994:57) praat in hierdie geval van 'n "linguistiese skisofrenie" van die Xhosa en Afrikaanse respondente wat sterk gekontrasteer word deur die Engelse respondente se onvoorwaardelike vertroue in hul eie taal.

Engels word deurgaans deur al drie groepe respondente baie hoog aangeslaan op funksionele, pragmatiese vlak. Die Afrikaanssprekende respondente ken aan Afrikaans status toe op akademiese gronde en, ten spyte van die feit dat dit op ekstensiewe wyse gebruik word vir private en persoonlike gesprekke, toon die navorsing dat Afrikaanssprekendes deurgaans min vertroue het dat Afrikaans uiteindelik sy amptelike status sal behou. Die navorsers kom tot die gevolgtrekking dat die posisie van Afrikaans in die Oos-Kaap korreleer met dié van minderheidstale wêreldwyd.

Uiteindelik word gesê dat die situasie van Afrikaans in die Oos-Kaap toegeskryf kan word aan die klein hoeveelheid eentalige Afrikaanssprekendes en die politieke kleur wat aan Afrikaans kleef. 'n Reaksie wat verreikende implikasies het vir die voortbestaan van Afrikaans in die OosKaap is dat die respondente oor die algemeen 'n groter verdraagsaamheid teenoor Xhosa as teenoor Afrikaans toon.

Desnieteenstaande dui die navorsers aan dat daar deur hierdie studie bewys kan word dat daar tog 'n sprankie hoop kan wees vir minderheidstale ten spyte van ' $n$ neiging om al die tale te ignoreer en vir amptelike doeleindes slegs deur medium van één algemene kommunikasietaal te kommunikeer.

\subsection{2 'n Evaluering van die onderneemde taalgesindheidstudies in Suid-Afrika}

Dit word uit die voorgaande bespreking duidelik dat daar oor 'n tydperk van twintig jaar sowat elf navorsingspublikasies verskyn het wat op 
taalgesindhede/-houdings fokus. Dube (1992:1) sê in dié verband dat daar binne die Suid-Afrikaanse konteks nog nie veel tereg gekom het van 'n omvattende en deurlopende studie van taalgesindhede nie. Veral opvallend is die afwesigheid van taalgesindheidsbeplanning binne die wetenskap van taalbeplanning vir die Suid-Afrikaanse konteks. Webb et al. (1992:37) wys tereg daarop dat taalhoudings die geslaagde implementering van taalplanne beïnvloed en om hierdie rede in berekening gebring moet word wanneer taalbeplanning gedoen word. Hoewel insiggewende afleidings telkens gemaak is ten opsigte van taalgemeenskappe se gehuldigde persepsies teenoor veral Afrikaans en Engels, is dit opvallend dat geeneen van die navorsingsresultate aandui watter implikasies dit vir die toekomstige beplanning van die betrokke tale het nie.

Webb (1992:434 e.v.) identifiseer bepaalde tekortkomings in reeds onderneemde studies van taalgesindhede in Suid-Afrika:

* Die studiefokus is hoofsaaklik beperk tot Afrikaans en Engels en die ander nege inheemse tale het agterweë gebly.

* Hoewel dié onderwerp in die sewentigerjare aandag gekry het, is daar nie werklik sprake van kontinuïteit in die navorsing nie. Daarby dra die verpolitiseerde Suid-Afrikaanse samelewing daartoe by dat die onderneemde navorsingsresultate van destyds nie meer as geloofwaardig beskou kan word nie.

* Vervolgens word die steekproefneming as uiters selektief beskou. Hierdie tekortkoming maak dit onmoontlik om afleidings te mak ten opsigte van die breë Suid-Afrikaanse bevolking se algemene taalgesindhede.

* Ook word die navorsingsmetodologie in twyfel getrek en word gesê dat die gebruikte metodes onvergelykbare data opgelewer het.

* Daarby het die ondemeemde studies meer op taalmenings gefokus en nie as sodanig aandag gegee aan taalgesindhede nie.

\section{Samevatting en gevolgtrekking}

\subsection{Samevatting}

Die aanvanklike probleemstelling by dié artikel was dat die algemene persepsie bestaan dat die lewendige openbare debat oor Afrikaans nie 
substansiële voordele vir die behoud van die amptelike status vir die taal inhou nie. Daarom was die doel met hierdie artikel om op verkennende wyse die kwessie van taalgesindhede in 'n breë teoretiese raamwerk te plaas en te bepaal in watter mate 'n wetenskaplike verdiskontering van taalgesindhede teenoor Afrikaans 'n positiewe uitwerking kan hê op die proses van taalstatusbeplanning.

Die artikel het op die volgende wyse ontplooi:

* Eerstens is ' $n$ begripsomskrywing gegee en is aangevoer dat die begrip taalgesindheid verkieslik is bo die algemeen gebruikte taalhouding.

* Tweedens is gelet op die algemene inherente eienskappe van gesindhede, word daar tot 'n definisie van taalgesindhede gekom en word dit bestempel as ' $n$ individuele of kollektiewe stel oortuigings teenoor 'n taal/variëteit en sy sprekers.

* Derdens dui dié artikel aan dat gesindhede oor die algemeen uit kognitiewe, affektiewe en konatiewe eienskappe bestaan en dat, vanweë die sosio-maatskaplike aard van taalgesindhede, dit 'n belangrike gemeenskapsrol kan speel as merker van veranderende gemeenskapsopvattinge oor 'n taalgemeenskap se persepsie teenoor 'n spesifieke taal/variëteit en/of sy sprekers.

* Vervolgens is die hele kwessie van taalgesindhede teen die agtergrond van taalbeplanning as wetenskap bestudeer en is tot die gevolgtrekking gekom dat dit tuishoort binne taalstatusbeplanning. Hierdie kategorisering word nie alleen onderskryf deur die feit dat gesindheidsbeplanning ' $n$ inherente deel van die doelwitbepalingsfase van enige taalstatusbeplanningsprojek is nie, maar ook deur die feit dat die kliënte van ' $n$ taalbeplanningsproses se persepsie van die afloop van sodanige projek behoorlik in berekening gebring moet word wanneer taalbeplanning gedoen word.

* Vyfdens is gelet op die verskillende faktore wat as determinante vir die bepaling van taalgesindhede optree en word taalgedrag, sosiale oordele, taalbeleidskwessies en institusionele ondersteuning as die hoofdeterminante onderskei.

* Die artikel sluit af met 'n oorsig oor taalgesindheidstudies wat die afgelope twintig jaar in Suid-Afrika onderneem is en wat spesifiek 
fokus op die primêre en sekondêre taalgemeenskappe se persepsies teenoor Afrikaans.

\subsection{Gevolgtrekking}

Die gevolgtrekking waartoe uiteindelik gekom word, is dat die doelbewuste beplanning van taalgesindhede op 'n akademies-verantwoordbare manier binne taalbeplanning verdiskonteer móét word ten einde die suksesvolle afloop van sodanige projek te verseker. Die literatuuroorsig bied die insig dat dit oor die loop van twintig jaar nog nooit gedoen is nie. Op sy beurt bied hierdie afleiding ' $n$ verklaring vir die noodsaak daarvan dat taalgemeenskappe se gesindhede op 'n duidelik omskrewe manier in berekening gebring moet word wanneer taalstatusbeplanning vir Afrikaans gedoen word.

As taalbeplanners in gebreke sou bly om op akademiese wyse kennis te neem van taalgesindhede en -persepsies en as hulle sou nalaat om op 'n verantwoordbare wyse die aandeel van gesindhede in die taalstatusproses te bestuur, loop die taalbeplanningsproses vir Afrikaans - en trouens vir die totale multitalige Suid-Afrikaanse gemeenskap - gevaar om skipbreuk te ly.

\section{Literatuurlys}

Agheyisi, R. \& Fishman, J. A. 1970. Language Attitude Studies: A Brief Survey of Methodological Approaches. Anthropological Linguistics, 12:131-157.

Baker, C. 1992. Attitudes and Language. Clevedon: Multilingual Matters. Booyse, C. 1992. Onderrigstrategiee ter verbetering van die houding van leerlinge teenoor Afrikaans as skoolvak. Potchefstroom : PU vir CHO. (M.A.verhandeling.)

Cahill, S. \& Kamper, G.D. 1989. Die stand, plek en rol van Afrikaans as tweedetaal in die breë kurrikulum van sekondêre skole in die Departement van Onderwys en Opleiding. Pretoria : RGN.

Carstens, W.A.M. 1994. Om ou koeie uit die sloot te grawe: is daar lesse te leer uit die verlede? - Enkele kantaantekeninge. Literator, 15(2):19-33.

Coetser, A. 1993. Afrikaans in die Transkei - 'n ondersoek na enkele sosiokulturele aspekte daarvan. Suid-Afrikaanse Tydskrif vir Taalkunde, 11(4):121-129. 
Cooper, R.L. 1984. Language Planning, Language Spread and Language Change. In: Kennedy, C. (ed.) Language Planning and Language Education. London: George Allen. p. 17-36.

Cooper, R.L. 1989. Language Planning and Social Change. Cambridge : Cambridge University Press.

De Klerk, V. \& Bosch, B. 1994. Language Attitudes in the Eastern Cape: A Tri-Lingual Survey. Suid-Afrikaanse Tydskrıf vir Taalkunde, 12(2):50-59.

De Villiers, Anita. 1992. Die implikasies van taalinterne konflik in Afrikaans vir opvoedkundige prestasie. In: Webb, V. (red.) Afrikaans na apartheid. Pretoria : Van Schaik. p. 287-317.

Dube, M.M.R. 1992. Language Attitudes in Soweto - the Place of Indigenous Languages. Soweto: Vista. (M.A.-verhandeling.)

Du Plessis, H. 1989. Die anatomie van taalbeplanning. Koers, 54(3):272-289.

Du Plessis, Hans. 1992. En nou, Afrikaans? Pretoria : Van Schaik.

Fishman, J.A. (ed.). 1976. Advances in the Sociology of Language. Volume 1. The Hague : Mouton.

Gouws, L.A. (et al.) 1979. Psigologiewoordeboek. Johannesburg : McGrawHill.

Haugen, E. 1983. The Implementation of Corpus Planning: Theory and Practice. In: Cobarnubias, J. \& Fishman, J.A. (eds.). Progress in Language Planning: International Perspectives. Berlin : Mouton. p. 267-289.

Hauptfleisch, T. 1983. Language Loyalty in South Africa. Volume 4: Language Loyalty and Language Shift: Some Trends among White Adults in Urban Areas. Pretoria : HSRC.

Jordaan, A., Van Rensburg, M.C.J., Webb, V.N. 1992. Ongepubliseerde navorsingsverslag oor 'n ondersoek na taalhoudings onder st. 9-leerlinge aan drie Afrikaansmedium hoërskole in Pretoria. Pretoria : Universiteit van Pretoria.

Kotze, E.F. 1987. Onbekend maak onbemind, of familiarity breeds contempt? Suid-Afrikaanse Tydskrif vir Taalkunde, 5(3):46-63.

Louw-Potgieter, J. \& Louw, J. 1991. Language Planning: Preferences of a Group of South African Students. Suid-Afrikaanse Tydskrif vir Taalkunde, 9(4):96-99.

Macauley, R.K.S. 1975. Negative Prestige, Linguistic Insecurity and Linguistic Self-Hatred. Lingua, 36:147-161.

Prinsloo, K.P. 1984. Gesindhede ten opsigte van taal in die onderwys in SuidAfrika. In: Prinsloo, K.P. \& Van Rensburg, M.C.J. (reds.) Afrikaans: stand, taak, toekoms. Pretoria : HAUM. p. 108-123. 
Rubin, J. 1983. Evaluation of Status Planning: What Has the Last Decade Accomplished? In: Cobarrubias, J. \& Fishman, J.A. (eds.). Progress in Language Planning: International Perspectives. Berlin : Mouton. p. 329344.

Saville-Troike, M. 1990. The Ethnography of Communication. Oxford : Blackwell.

Scheffer P. 1983. Afrikaans en Engels onder die Kleurlinge in die Kaapprovinsie, in besonder die Skiereiland. Pretoria : RGN.

Schuring, G.K. 1979. A Multilingual Society: English and Afrikaans amongst Blacks in the RSA. Pretoria : HSRC.

Schoonees, P.C. (hoofred.) 1972. Woordeboek van die Afrikaanse Taal. Deel III (G) \& IV (H-I). Pretoria : Staatsdrukker.

Steyn, J.C. 1980. Tuiste in eie taal. Kaapstad : Tafelberg.

Steyn, J.C. 1992. Die behoud van Afrikaans as ampstaal. In: Webb, V. (red.). Afrikaans na apartheid. Pretoria : Van Schaik. p. 203-225.

Swanepoel, P. 1992. Taal, emosies en die toekoms van Afrikaans. In: Webb, V. (red.). Afrikaans na apartheid. Pretoria : Van Schaik. p. 119-163.

Van der Merwe, E. 1990. Taalbeplanning. Suid-Afrikaanse Tydskrif vir Taalkunde, 8(4):185-193.

Van Jaarsveld, G.J. 1989. Gesprekstaboes en misverstand: Taalhandelinge oor kultuurgrense heen. Bloemfontein : UOVS. (Navorsingsverslag.)

Verhoef, M.M. 1991. Taalbeplanning: die stand en toekoms van taalbeplanning vir Afrikaans in 'n multitalige Suid-Afrika. Potchefstroom : PU vir CHO. (Ph.D-proefskrif.)

Vorster, J. \& Proctor, L. 1975. Black Attitudes to White Languages in South Africa. Journal of Psychology, 92(1):103-108.

WAT

$k y k$

Schoonees, P.C. 1972.

Wardhaugh, R. 1987. Languages in Competition. Oxford : Blackwell.

Webb, V. 1992. Language Attitudes in South Africa: Implications for a PostApartheid South Africa. In: Pütz, M. (ed.). Thirty Years of Linguistic Evolution. Philadelphia : John Benhamins Publishing Company. p. 429460.

Webb, V., Dirven, R, \& Kock, E. 1992. Afrikaans: feite en interpretasies. In: Webb, V. (red.). Afrikaans na apartheid. Pretoria : Van Schaik. p. 25-67. 